\title{
Cave Cyanobacteria showing antibacterial activity
}

\author{
Vasiliki Lamprinou $^{1}$, Kyriaki Tryfinopoulou ${ }^{2}$, Emmanuel N. Velonakis ${ }^{2,3}$, \\ Alkiviadis Vatopoulos ${ }^{2,3}$, Smaragdi Antonopoulou ${ }^{4}$, Elizabeth Fragopoulou ${ }^{4}$, \\ Adriani Pantazidou ${ }^{1}$, and Athena Economou-Amilli ${ }^{*}$ \\ ${ }^{1}$ University of Athens, Faculty of Biology, Department of Ecology \& Systematics, Panepistimiopolis, Athens 15784 , Greece \\ ${ }^{2}$ Central Public Health Laboratory, 34 Al. Fleming, 16672, Vari, Athens, Greece \\ ${ }^{3}$ Department of Microbiology, National School of Public Health, 196 Alexandras Avenue, Athens 11521, Greece \\ ${ }^{4}$ Harokopio University, Department of Nutrition \& Dietetics, 70 El. Venizelou, Athens 17671, Greece
}

\begin{abstract}
Cave Cyanobacteria - thriving in an 'extreme' environment with interesting species biodiversity - are supposed to be a potential source of bioactive compounds. Lipid extracts from pure cultures of two recently established Cyanobacteria from Greek caves, Toxopsis calypsus and Phormidium melanochroun, were used for antibacterial screening against human pathogenic bacteria (reference and clinical isolates). Antimicrobial Susceptibility testing for both taxa was carried out using the disc-diffusion (Kirby Bauer) method, while preliminary data applying the standard broth microdilution method for the determination of the Minimal Inhibitory Concentration (MIC) are given only for T. calypsus. Antibacterial activity was demonstrated against the Gram-positive clinical and reference bacteria, mostly pronounced in enterococci; no activity was observed against the Gram-negative bacteria. The above screening is the first record of antibacterial activity from lipid extracts of cave Cyanobacteria enhancing the importance of cave microbiota and the necessity for cave conservation.
\end{abstract}

Keywords: $\quad$ cave Cyanobacteria; Toxopsis calypsus; Phormidium melanochroun; antimicrobial susceptibility screening

Received 29 December 2014; Revised 9 March 2015; Accepted 27 April 2015

Citation: Lamprinou V., Tryfinopoulou K., Velonakis E.M., Vatopoulos A., Antonopoulou S., Fragopoulou E., Pantazidou P. \& Economou-Amilli A., 2015. Cave Cyanobacteria showing antibacterial activity. International Journal of Speleology, 44 (3), 231-238. Tampa, FL (USA) ISSN 0392-6672 http://dx.doi.org/10.5038/1827-806X.44.3.2

\section{INTRODUCTION}

Cyanobacteria represent a group of Gram-negative photoautotrophic prokaryotes thriving in almost all aquatic and terrestrial habitats on earth, including extreme environments. This widespread distribution reflects the tolerance of Cyanobacteria towards environmental stress due, inter alia, to a broad spectrum of specific properties in physiology (Uzair et al., 2012). Generally, microorganisms forming microbial mats in extreme environments have been recently identified as a good source of bioactive compounds for different biotechnological applications (Harvey, 2000; Dobretsov et al., 2011).

Modern research has focused on a variety of bioactive compounds produced by Cyanobacteria. After analysis of a great number of marine cyanobacterial natural products, lipopeptides seem to prevail followed at much lesser proportions by amino acids, fatty acids, macrolides and amides (Burja et al., 2001; Singh et al., 2011; Engene et al., 2013). These interesting and biochemically active compounds possess biological activity covering a wide range of antibacterial (Mundt et al., 2003; Kaushik \& Chauhan, 2008; Ramadan et al., 2008; Asthana et al., 2009; Kaushik et al., 2009; Khairy \& El-Kassas, 2010; Suhail et al., 2011), antifungal (MacMillan et al., 2002), antialgal (Papke et al., 1997), antiviral (Hayashi et al., 1996; Zainuddin et al., 2002), anti-thrombotic (Antonopoulou et al., 2002; $2005 \mathrm{a}, \mathrm{b})$ and also anticancer effectiveness (Luesh et al., 2001; Simmons et al., 2005).

Many Cyanobacteria from various biotopes have been tested for antibacterial activity, e.g. marine (Luesh et al., 2001; Simmons et al., 2005; Mathew et al., 2008; Vijaya Baskara Sethubathi \& Ashok Prabu, 2012), freshwater (Østensvik et al., 1998; Mian et al., 2003; Madhumathi et al., 2011) and terrestrial (Mian et al., 2003; Abdel-Raouf \& Ibraheem, 2008; Ramamurthy et al., 2012). Considering cave ecosystems as an extreme environment (due to the insufficient light 
and nutrient limitation), antibiotic effectiveness by cave bacteria has recently been recorded (Montano \& Henderson, 2013); however, no studies have yet identified the antibacterial potential of cyanobacterial isolates from caves.

Exploitation of new natural products as antibacterial agents against resistant pathogens is very important for clinical medicine and public health, and a limited number of new antimicrobial classes have been developed by the international pharmaceutical industry in the last 20 years (Infectious Diseases Society of America, 2007). The aim of the present study is to assess the potential antibacterial activity of extracts from two recently established Cyanobacteria from Greek caves, i.e. Toxopsis calypsus and Phormidium melanochroun (Lamprinou et al., 2012, 2013). It is noted that cave environments are still relatively underexploited, and may prove to be a rich source of novel biodiversity possessing bioactive compounds potentially useful in biotechnology.

\section{MATERIAL AND METHODS}

\section{Sampling}

Fresh material, as scrapped mats and pieces of rocks of $\leq 5 \mathrm{~g}$, was collected from 'Francthi' Cave $\left(37^{\circ} 25^{\prime} 21.01^{\prime \prime} \mathrm{N}, \quad 22^{\circ} 17^{\prime} 51.18^{\prime \prime} \mathrm{N}\right.$; altitude $12.5 \mathrm{~m}$ a.s.1.), an exposed, non typical cave, with partly collapsed roof, located in Argolida (Peloponnese, Greece). Sampling was conducted seasonally at seven selected sites from the entrance inwards. Temperature (average $18.26^{\circ} \mathrm{C}, \min 11.53^{\circ} \mathrm{C}, \max 25.94^{\circ} \mathrm{C}$ ), Relative Humidity (average 66.20\%, min 50.73\%, max 93.51\%) and photosynthetically active radiation (average $3.09 \mu \mathrm{mol} \cdot \mathrm{s}^{-1} \cdot \mathrm{m}^{-2}$, min $0.08 \mu \mathrm{mol} \cdot \mathrm{s}^{-1} \cdot \mathrm{m}^{-2}$, max 26.70 $\mu \mathrm{mol} \cdot \mathrm{s}^{-1} \cdot \mathrm{m}^{-2}$ ) were measured at each sampling site and sampling date by a LI-1400 data logger (LI-COR Biosciences, USA). Four subsamples were collected from each sampling site. Two of them were incubated in situ into sterile transparent vials and, the other two were partly fixed with formaldehyde solution at 2.5\%. Enrichment cultures were obtained in flasks and petri dishes with culture media (BG $11_{\circ}$ and BG 11 , Stanier et al., 1971) and under proper conditions (Gallenkamp, Sanyo incubator; $23^{\circ} \mathrm{C}, 80 \% \mathrm{RH}$, 7 umols $\cdot \mathrm{s}^{-1} \cdot \mathrm{m}^{-2}$ ). The two Cyanobacteria selected for antibacterial screening (Tables $1 \mathrm{a}, \mathrm{b})$ were: (i) Toxopsis calypsus (type strain: ATHU-CY 3314, GenBank acc. Nr. JN695681-JN695685) found at the nearest to the entrance site, and (ii) Phormidium melanochroun (type strain: ATHU-CY 3315, GenBank acc. Nr. JQ692233) found in almost all sampling sites. The required time for attaining sufficient biomass for lipid extraction was 150-200 days.

\section{Lipids Extraction and Thin Layer Chromatography (TLC)}

Total lipids were extracted from cell suspensions of cultures using the Bligh Dyer method (Bligh \& Dyer, 1959). Total lipids (TLs) were then separated into polar (PLs) and neutral lipids (NLs) by countercurrent distributions in a binary system formed by mixing three volumes of pre-equilibrated petroleum ether and one volume of pre-equilibrated $87 \%$ ethanol (Galanos $\&$ Kapoulas, 1962). The PLs were further fractioned by Thin Layer Chromatography (TLC) on ten (10) TLC plates using chloroform/acetone/methanol/ acetic acid/water at a ratio of 100:40:34:10:10 $(\mathrm{v} / \mathrm{v} / \mathrm{v} / \mathrm{v} / \mathrm{v})$ as developing system. Appropriate standards of phospho- and glycol-lipids were also used. After exposure of the TLC plate to $\mathrm{I}_{2}$ vapor, the fractions of PLs were scraped off separately, centrifuged, and the organic solvents were phased by adding appropriate volumes of chloroform, methanol and water at a ratio of 1:2:0.8 (v/v/v). All reagents and chemicals were of analytical grade and supplied by Merck (Darmstadt, Germany). The chromatographic material used for TLC was silica gel H-60 (Merck, Darmstadt, Germany).

\section{Antibacterial activity determination}

The potential antibacterial activity was tested in both Cyanobacteria strains by the disk diffusion method with Mueller-Hinton II agar (OXOID, UK) according to CLSI guidelines. Dried extracts were dissolved in methanol. The plates were inoculated with a suspension of each strain adjusted to a turbidity of 0.5 McFarland. Sterilized blank (3 $\mathrm{mm}$ Chr Whatman) paper disks $(6 \mathrm{~mm}$ diameter) were applied to the surface of the inoculated agar and were loaded with a total amount of $10 \mu l$ and $20 \mu 1$ of each extract solution. The antibiotic disks (BIORAD, UK) gentamicin $10 \mu \mathrm{g}(\mathrm{GEN})$, ampicillin $10 \mu g$ (AMP), cefoxitin $30 \mu g$ (FOX), tetracycline $30 \mu \mathrm{g}$ (TET), ciprofloxacin $5 \mu \mathrm{g}$ (CIP) and co-trimoxazole 1.25 / $23.75 \mu \mathrm{g}$ (SXT) were used as positive controls depending of the bacterial species. Methanol alone was used as a negative control since a volume of $\mathrm{V} \geq 5 \mu \mathrm{l}$ pure methanol was inhibitory to bacterial growth. The plates were left to dry for $15 \mathrm{~min}$ and were incubated for $18 \mathrm{~h}$ at $35^{\circ} \pm 2^{\circ} \mathrm{C}$. For all agents the diameters of zones of inhibition were measured to the nearest millimeter and for the positive controls the results were interpreted according to CLSI (2012) breakpoints. Each fraction of PLs, as well as the NLs as a whole, was tested in vitro for their ability to inhibit growth of the following eight reference or clinical isolates: S. aureus NCTC 6571, Methicillin-Resistant S. aureus (MRSA) 1629, Methicillin-Susceptible S. aureus (MSSA) 1646, Enterococcus faecalis ATCC 29212, Vancomycin-Resistant E. faecalis (VRE) 880, Vancomycin-Resistant E. faecium (VRE) 1291, Escherichia coli ATCC 25922, and Pseudomonas aeruginosa ATCC 27853.

After the initial evaluation of antibacterial activity, the Minimum Inhibitory Concentrations (MICs) were determined only for $T$. calypsus by broth microdilution method as recommended by CLSI. The tests were performed in sterile 96-well microtiter plates. Briefly, $50 \mu \mathrm{l}$ of two-fold serial dilutions of examined samples was added to $50 \mu 1$ microbial suspensions adjusted to yield approximately $5 \times 10^{5} \mathrm{CFU} / \mathrm{ml}$. MIC was encountered as the lowest concentration of the examined sample that inhibits the visible microbial growth after $24 \mathrm{~h}$ incubation at $37^{\circ} \mathrm{C}$. Negative controls (methanol) were included, too. 

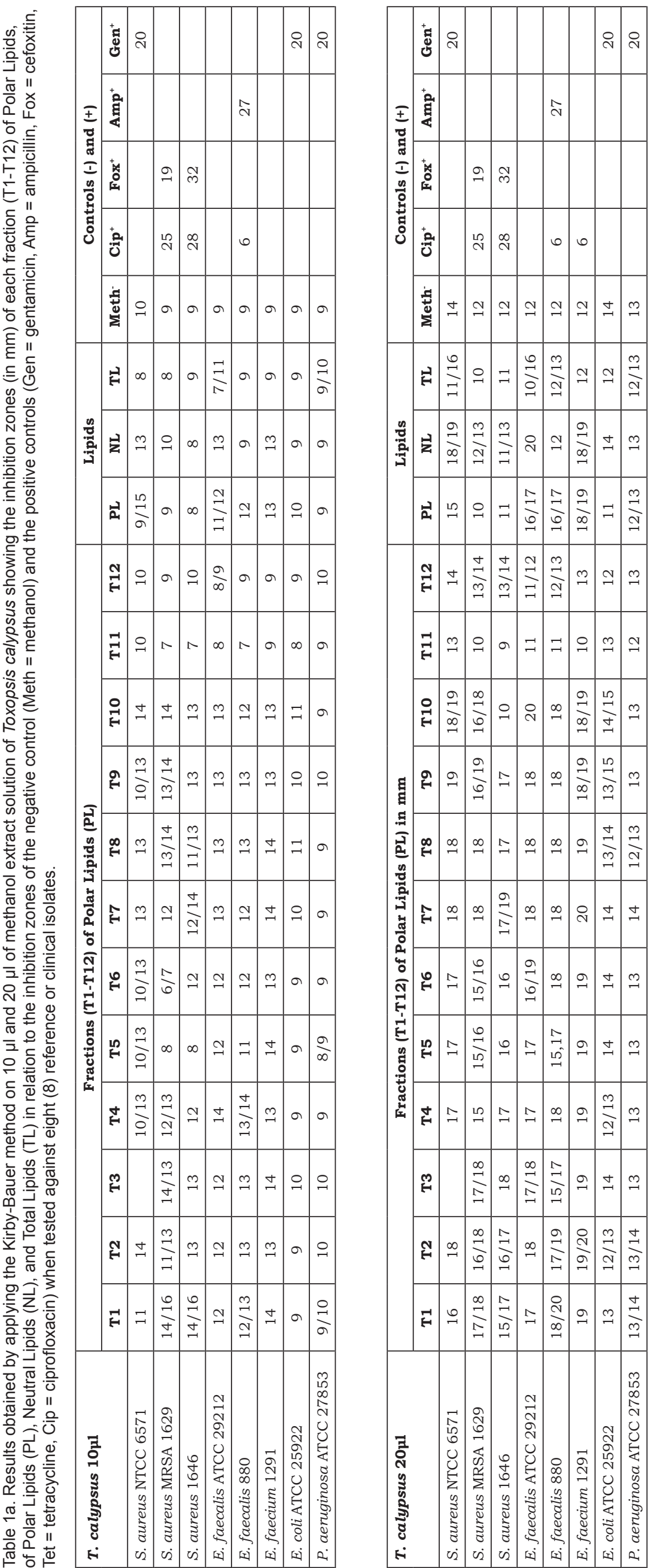

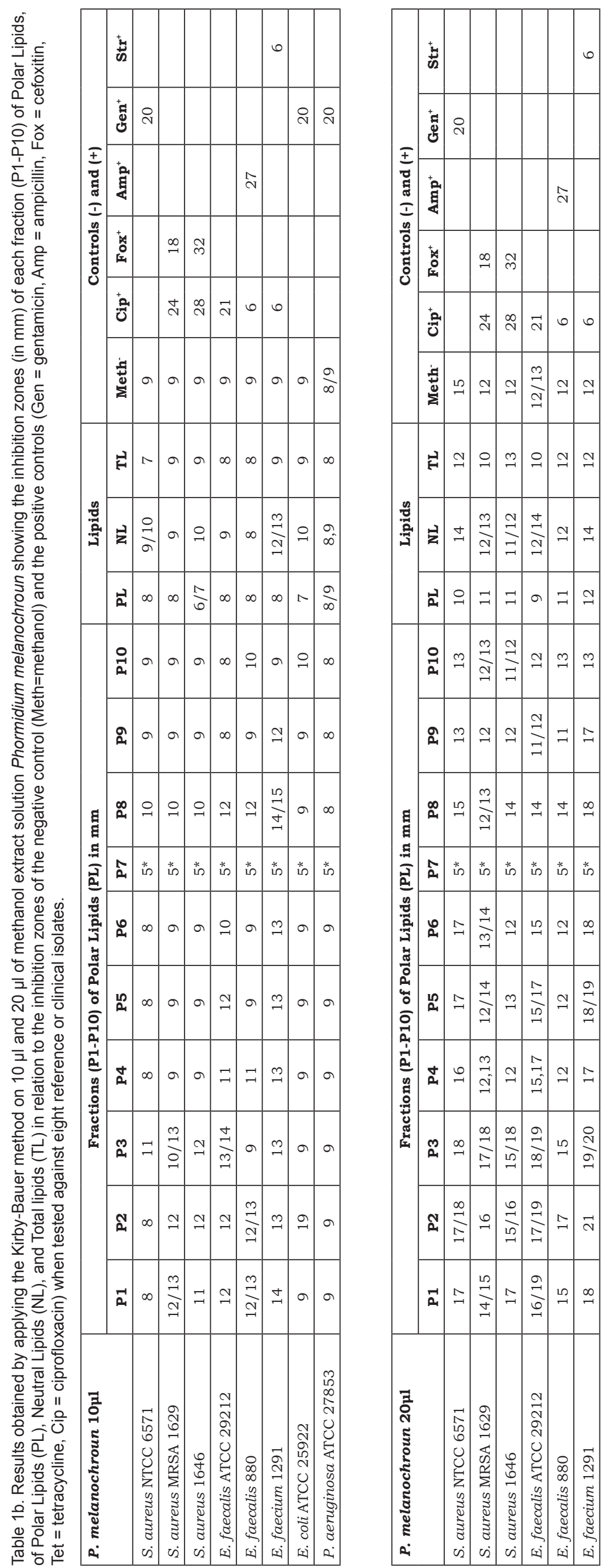


\section{RESULTS}

Extraction of lipids from the Cyanobacteria $T$. calypsus and $P$. melanochroun yielded about $31 \mathrm{mg}$ and $51 \mathrm{mg}$ of total lipids (TLs), respectively. Polar lipids (PLs) were further fractioned by TLC, and after exposure in $\mathrm{I}_{2}$ vapor a total of 12 and 10 bands were revealed for $T$. calypsus and $P$. melanochroun, respectively. The retention factors (Rfs) for each band of polar lipids compared to that of standards are shown in Table 2.

As examined by the Kirby Bauer Method, each fraction of PLs from both Cyanobacteria species, as well as TLs, PLs and NLs as a whole, yielded an inhibition halo against the examined Gram-positive bacteria, whereas none of the examined lipids was effective against the Gram-negative bacteria (Tables $1 \mathrm{a}, \mathrm{b})$.

Among the Gram-positive bacteria, the reference and clinical isolates of enterococci were mostly affected since a greater number of fractions of PLs (including NLs and PLs as a whole) showed zones of inhibition. The highest zones of inhibition $(20 \mathrm{~mm})$ were observed: (i) against Enterococcus faecium (VRE) by the fractions T2 and T7 of T. calypsus, and by the fraction P3 of P. melanochroun, at a total volume of $20 \mu \mathrm{l}$, and (ii) against Enterococcus faecalis (ATCC) by the fraction T9 of $T$. calyspsus also at a total volume of $20 \mu 1$. One fraction of polar lipids (P7) from P. melanochroun showed no zone of inhibition eliminating the expected halo of pure methanol (see Table $1 \mathrm{a}, \mathrm{b}$ ).

The results obtained by the broth microdilution method (MICs) for T. calypsus confirm those of the disk diffusion method (Table 3). Antibacterial activity of the 12 fractions of PLs (including NLs and PLs as a whole) extracted from $T$. calypsus was recorded against staphylococci and enterococci in MIC values $0.256 \mu \mathrm{g} / \mathrm{ml}$ and $0.512 \mu \mathrm{g} / \mathrm{ml}$. Seven (7) fractions of PLs (T1-T3, T7-T10) showed the greatest MIC values against enterococci $(0.256 \mu \mathrm{g} / \mathrm{ml})$. Moreover, one of the above fractions (T10) showed antibacterial activity against $S$. aureus (MRSA) at MIC value of $0.256 \mu \mathrm{g} / \mathrm{ml}$. The fractions T11 and T12 indicated no antibacterial activity at $\mathrm{MIC} \geq 0.512 \mu \mathrm{g} / \mathrm{ml}$.

Table 2. Retention factors (average \pm standard deviation) for each fraction (T1-T12) of Polar Lipids of Toxopsis calypsus and for each fraction (P1-P10) of Polar Lipids of Phormidium mealanochroun compared to the retention factors given for the following standards: LPC = lysophosphatidyl-choline; SM = sphingomyelin; $\mathrm{PC}=$ phosphatidyl-choline; $\mathrm{PE}=$ phosphatidyl-ethanolamine; SULF = sulfatides; $\mathrm{DGDG}=$ digalactosyldiglycerides; GALCER = galactosyl-cerebrosides; CERA = ceramides.

\begin{tabular}{|c|c|c|c|c|}
\hline \multicolumn{2}{|c|}{ Retention Factors (Rf) } \\
\hline \multicolumn{2}{|c|}{ Toxopsis calypsus } & \multicolumn{2}{|c|}{ Phormidium melanochroun } & Standards \\
\hline T1 & $0.153 \pm 0.009$ & P1 & $0.151 \pm 0.024$ & LPC $=0.08$ \\
T2 & $0.202 \pm 0.027$ & P2 & $0.196 \pm 0.018$ & SM $=0.17$ \\
T3 & $0.256 \pm 0.020$ & P3 & $0.268 \pm 0.015$ & PC $=0.28$ \\
PE $=0.57$ & SULF $=0.61$ \\
T4 & $0.304 \pm 0.017$ & P4 & $0.355 \pm 0.050$ & DGDG $=0.71$ \\
GA & GEER $=0.78$ \\
CERA $=0.93$
\end{tabular}

Table 3. Minimum Inhibitory Concentration (MIC) values (in $\mu \mathrm{g} / \mathrm{ml}$ ) determined for each methanol fraction (T1-T12) of Polar Lipids, as well as of Polar Lipids (PL), Neutral Lipids (NL) and Total Lipids (TL) of Toxopsis calypsus when tested against eight reference or clinical isolates.

\begin{tabular}{|c|c|c|c|c|c|c|c|c|}
\hline & $\begin{array}{c}\text { S. aureus } \\
\text { NTCC } 6571\end{array}$ & $\begin{array}{c}\text { S. aureus } \\
\text { MRSA } 1629\end{array}$ & $\begin{array}{c}\text { S. aureus } \\
\text { MSSA } 1646\end{array}$ & $\begin{array}{c}\text { E. faecalis } \\
\text { ATCC } 29212\end{array}$ & $\begin{array}{l}\text { E. faecalis } \\
\text { VRE } 880\end{array}$ & $\begin{array}{l}\text { E. faecium } \\
\text { VRE } 1291\end{array}$ & $\begin{array}{c}\text { E. coli ATCC } \\
25922\end{array}$ & $\begin{array}{c}\text { P. aeruginosa } \\
\text { ATCC } 27853\end{array}$ \\
\hline $\mathrm{T} 1$ & 0.512 & 0.512 & 0.512 & 0.256 & 0.256 & 0.256 & - & - \\
\hline $\mathrm{T} 2$ & 0.512 & 0.512 & 0.512 & 0.256 & 0.256 & 0.256 & - & - \\
\hline T3 & 0.512 & 0.512 & 0.512 & 0.256 & 0.256 & 0.256 & - & - \\
\hline $\mathrm{T} 4$ & 0.512 & 0.512 & 0.512 & - & - & - & - & - \\
\hline T5 & 0.512 & 0.512 & 0.512 & - & - & - & - & - \\
\hline T6 & - & - & 0.512 & - & - & - & - & - \\
\hline $\mathrm{T} 7$ & 0.512 & 0.512 & 0.512 & 0.256 & 0.256 & 0.256 & - & - \\
\hline T8 & 0.512 & 0.512 & 0.512 & 0.256 & 0.256 & 0.256 & - & - \\
\hline T9 & 0.512 & 0.512 & 0.512 & 0.256 & 0.256 & 0.256 & - & - \\
\hline T10 & 0.512 & 0.512 & 0.256 & 0.256 & 0.256 & 0.256 & - & - \\
\hline $\mathrm{T} 11$ & - & - & - & - & - & - & - & - \\
\hline $\mathrm{T} 12$ & - & - & - & - & - & - & - & - \\
\hline $\mathrm{PL}$ & - & - & - & 0.512 & 0.512 & 0.512 & - & - \\
\hline $\mathrm{NL}$ & - & - & - & 0.512 & 0.512 & 0.512 & - & - \\
\hline TL & - & - & - & 0.512 & 0.512 & 0.512 & - & - \\
\hline
\end{tabular}




\section{DISCUSSION}

Natural products have been attributed to a few genera within Cyanobacteria, given that some of them were proved to be polyphyletic groups, e.g. genus Lyngbya was shown to be composed of several phylogenetically distant and unrelated lineages (Sharp et al., 2009; Engene et al., 2010, 2012, 2013; Komárek et al., 2013). Moreover, phylogenetic inferences of marine cyanobacterial strains responsible for over 100 bioactive secondary metabolites revealed an uneven taxonomic distribution, with a few groups being responsible for the vast majority of these molecules (Engene et al., 2013). These data suggest a high degree of novel biodiversity among natural product-producing strains that was previously overlooked by traditional morphology-based taxonomic approaches.

The two species selected for this study are new Cyanobacteria from Greek caves established by both the traditional and the molecular (polyphasic) approach (Lamprinou et al., 2012, 2013): a) Phormidium melanochroun is an oscillatorialean species characterized by a blackish thick mucilaginous sheath (autapomorphic character), and b) Toxopsis calypsus is a nostocalean species characterized by both isopolar and heteropolar life cycle (autapomorphic character). The observed outcompeting behaviour of the former species towards other Cyanobacteria in our cultures and the fact that previous studies were focused on different antibacterial compounds extracted from genus Phormidium (e.g. Madhumathi et al., 2011; Vijaya Baskara Sethubathi \& Prabu, 2012) making this genus a target in the search for a potential lipid antibacterial activity. On the other hand, the taxonomic position of the latter species ( $T$. calypsus) among Nostocales has been crucial in the search for a similar activity of lipids, since the order Nostocales is known for intense antibacterial and antifungal activity and has been the focus of many relevant investigations with Nostoc and Anabaena being the most well studied genera (Mundt et al., 2001; Abdel-Raouf \& Ibraheem, 2008; Asthana et al., 2009; Kausik et al., 2009).

Lipids and some free fatty acids from microalgae and Cyanobacteria are known to display antibacterial properties (Borowitzka, 1995; Desbois \& Smith, 2010; Plaza et al., 2010; Najdenski et al., 2013). In our study, most of the lipids extracted from $P$. melanochroun and T. calypsus demonstrated potential activity against the Gram-positive clinical and reference bacteria with pronounced effectiveness against the enterococci; on the contrary, no activity was observed against the Gram-negative bacteria (cf. Ramadan et al., 2008). Although the exact mechanism is rather unknown, lipids are supposed to be the responsible disrupting agents of the bacterial cellular membranes by penetrating into the thick peptidoglycan wall layer of the Gram-positive bacteria, but not affecting the thin peptidoglycan wall layer of the Gram-negative bacteria (Najdenski et al., 2013).

The MIC values of lipids from Toxopsis calypsus $(0.256 \mu \mathrm{g} / \mathrm{ml})$ were highly active against all tested enterococci in comparison with previously reported MIC values from crude extracts of other cyanobacterial strains (ranging from $0.5 \mathrm{mg} / \mathrm{ml}$ to $512 \mathrm{mg} / \mathrm{ml}$; e.g., Kaushik \& Chauhan, 2008; Asthana et al., 2009; Kumar et al., 2012). These data and future similar research on Phormidium melanochroun, accompanied by precise composition and characterization of these active compounds, are highly promising steps for developing effective antibiotics from cave Cyanobacteria in pharmaceutical industry.

Extreme habitats experiencing steady or fluctuating exposure to one or more environmental factors, i.e. salinity, osmolality, desiccation, solar irradiance, barometric pressure, $\mathrm{pH}$, temperature, nutrient limitation (Seufferheld et al., 2008; Dapkevicius, 2013) are considered as one of the most promising sources of biotechnologically useful compounds. As a result, several studies have been devoted to screening secondary metabolites produced by microorganisms inhabiting such environments (e.g., Harvey, 2000; Nicolaus etal., 2010; Chang etal., 2011; Singh \& Gabani, 2011). Caves are considered as extreme environments in terms of nutrient limitation and insufficient light with rather understudied microorganisms; thus, caves are promising sources for successful natural product research, justifying their conservation and our effort of screening the isolated Cyanobacteria.

\section{REFERENCES}

Abdel-Raouf A.N. \& Ibraheem I.B.M., 2008 - Antibiotic activity of two Anabaena species against four fish pathogenic Aeromonas species. African Journal of Biotechnology, 15: 2644-2648.

Antonopoulou S., Oikonomou A., Karantonis H.C., Fragopoulou E. \& Pantazidou A., 2002 - Isolation and structure elucidation of biologically active phospholipids from Scytonema julianum (Cyanobacteria). Biochemical Journal, 367: 287-293.

http://dx.doi.org/10.1042/BJ20020146

Antonopoulou S., Nomikos T., Oikonomou A., Kyriacou A., Andriotis M., Fragopoulou E. \& Pantazidou A., 2005 a - Characterization of bioactive glycolipids from Scytonema julianum (Cyanobacteria). Comparative Biochemistry and Physiology Part B: Biochemistry and Molecular Biology, 140: 219-231. http://dx.doi.org/10.1016/j.cbpc.2004.10.006

Antonopoulou S., Karantonis H.C., Nomikos T., Oikonomou A., Fragopoulou E. \& Pantazidou A., 2005 b - Bioactive polar lipids from Chroococcidiopsis sp. (Cyanobacteria). Comparative Biochemistry and Physiology Part B: Biochemistry and Molecular Biology, 142: 269-282.

http://dx.doi.org/10.1016/j.cbpc.2005.07.007

Asthana R., Deepali A., Tripathi M., Srivastava A., Singh A., Singh S., Nath G., Srivastava R. \& Srivastava B., 2009 - Isolation and identification of a new antibacterial entity from the Antarctic cyanobacterium Nostoc CCC 537. Journal of Applied Phycology, 21: 81-88. http://dx.doi.org/10.1007/s10811-008-9328-2

Bligh E. \& Dyer W.J., 1959 - A rapid method of total lipid extraction and purification. Canadian Journal of Biochemistry and Physiology, 37: 911-917. http://dx.doi.org/10.1139/o59-099

Borowitzka M., 1995 - Microalgae as sources of pharmaceuticals and other biologically active compounds. Journal of Applied Phycology, 7: 3-15. http://dx.doi.org/10.1007/BF00003544 
Burja A.M., Banaigs B., Abou-Mansour E., Grant Burgess J. \& Wright P.C., 2001 - Marine cyanobacteria - A prolific source of natural products. Tetrahedron, 57: 9347-9377.

http://dx.doi.org/10.1016/S0040-4020(01)00931-0

Chang C.C., Chen W.C., Ho T.F., Wu H.S. \& Wei Y.H., 2011 - Development of natural anti-tumor drugs by microorganisms. Journal of Bioscience and Bioengineering, 111: 501-511.

http://dx.doi.org/10.1016/j.jbiosc.2010.12.026

CLSI, 2012 - Performance standards for antimicrobial susceptibility testing. Twenty-Second Informational Supplement. CLSI document M100-S22. Wayne, PA: Clinical and Laboratory Standards Institute.

Dapkevicius MdLNE, 2013 - Cave biofilms and their potential for novel antibiotic discovery. In: Cheeptham N. (Ed.), Cave microbiomes: A novel resource for drug discovery. Springer Briefs in Microbiology. Springer, New York, p. 35-44.

Desbois A.P. \& Smith V.J., 2010 - Antibacterial free fatty acids: Activities, mechanisms of action and biotechnological potential. Applied Microbiology and Biotechnology, 85: 1629-1642.

http://dx.doi.org/10.1007/s00253-009-2355-3

Dobretsov S., Abed R.M.M., Maskari S., Sabahi J. \& Victor R., 2011 - Cyanobacterial mats from hot springs produce antimicrobial compounds and quorum-sensing inhibitors under natural conditions. Journal of Applied Phycology, 23: 983-993.

http://dx.doi.org/10.1007/s10811-010-9627-2

Engene N., Coates R.C. \& Gerwick W.H., 2010 - $16 S$ rRNA gene heterogeneity in the filamentous marine cyanobacterial genus Lyngbya. Journal of Phycology, 46: 591-601.

http://dx.doi.org/10.1111/j.1529-8817.2010.00840.x

Engene N., Rottacker E.C., Kaštovský J.H., Byrum T., Choi H., Komárek J. \& Gerwick W.H., 2012 - Moorea producens gen. nov., sp. nov. and Moorea bouillonii comb. nov., tropical marine cyanobacteria rich in bioactive secondary metabolites. International Journal of Systematic and Evolutionary Microbiology, 62: 1172-1179. http://dx.doi.org/10.1099/ijs.0.033761-0

Engene N., Gunasekera S.P., Gerwick W.H. \& Paul V.J., 2013 - Phylogenetic inferences reveal a large extent of novel biodiversity in chemically rich tropical marine cyanobacteria. Applied and Environmental Microbiology, 79: 1882-1888.

http://dx.doi.org/10.1128/AEM.03793-12

Galanos D.S. \& Kapoulas V.M., 1962 - Isolation of polar lipids from triglyceride mixtures. Journal of Lipid Research, 3: 134-137.

Harvey A., 2000 - Strategies for discovering drugs from previously unexplored natural products. Drug Discovery Today, 5: 294-300. http://dx.doi.org/10.1016/S1359-6446(00)01511-7

Hayashi T., Hayashi K., Maeda M. \& Kojima I., 1996 - Calcium spirulan, an inhibitor of enveloped virus replication, from a blue-green alga Spirulina platensis. Journal of Natural Products, 59: 83-87.

http://dx.doi.org/10.1021/np960017o

IDSA (Infectious Diseases Society of America), 2007 - Bad bugs, no drugs: as antibiotic discovery stagnates... a public health crisis brews. http://www.idsociety.org/ uploadedFiles/IDSA/Policy_and_Advocacy/Current Topics_and_Issues/Advancing_Product_Research_ and Development/Bad Bugs No Drugs/Statements/ As_Antibiotic Discovery Stagnates A Public Health Crisis Brews.pdf [accessed: January 3, 2007].
Kaushik P. \& Chauhan A., 2008 - In vitro antibacterial activity of laboratory grown culture of Spirulina platensis. Indian Journal of Microbiology, 48: 348-352. http://dx.doi.org/10.1007/s12088-008-0043-0

Kaushik P., Chauhan A., Chauhan G. \& Goyal P., 2009 - Antibacterial potential and UV-HPLC analysis of laboratory-grown culture of Anabaena variabilis. International Journal of Food Safety, 11: 11-18.

Khairy H.M. \& El-Kassas H.Y., 2010 - Active substance from some blue green algal species used as antimicrobial agents. African Journal of Biotechnology, 9: 2789-2800.

Komárek J., Zapomelová E., Smarda J., Kopecky J., Rejmánková E., Woodhouse J., Neilan B.A. \& Komárková J., 2013 - Polyphasic evaluation of Limnoraphis robusta, a water-bloom forming cyanobacterium from Lake Atitlan, Guatemala, with a description of Limnoraphis gen. nov. Fottea, 13: 39-52. http://dx.doi.org/10.5507/fot.2013.004

Kumar M., Tripathi M.K., Srivastava A., Nath G. \& Asthana R.K., 2012 - A comparative study of antibacterial activity of brackish and fresh water cyanobacterial strains. Asian Journal of Experimental Biological Sciences, 3: 548-552.

Lamprinou V., Skaraki K., Kotoulas G., Economou-Amilli A. \& Pantazidou A., 2012 - Toxopsis calypsus gen. nov., sp. nov. (Cyanobacteria, Nostocales) from cave 'Francthi', Peloponnese, Greece - Morphological and molecular evaluation. International Journal of Systematic and Evolutionary Microbiology, 62: 2870-2877. http://dx.doi.org/10.1099/ijs.0.038679-0

Lamprinou V., Skaraki K., Kotoulas G., Anagnostidis K., Economou-Amilli A. \& Pantazidou A., 2013 - A new species of Phormidium (Cyanobacteria, Oscillatoriales) from three Greek caves - Morphological and molecular analysis. Fundamental and Applied Limnology, 182: 109-116.

http://dx.doi.org/10.1127/1863-9135/2013/0323

Luesh H., Moore R.E., Paul V.J., Mooberry S.L. \& Corbett T.H., 2001 - Isolation of dolastatin 10 from the marine cyanobacterium Symploca species VP 642 and total stereochemistry and biological evaluation of its analogue symplostatin 1. Journal of Natural Products, 64: 907-910. http://dx.doi.org/10.1021/np010049y

MacMillan J.B., Ernst-Russell M.A., De Ropp J.S. \& Molinski T.F., 2002 - Lobocyclamides A-C, lipopeptides from a cryptic cyanobacterium mat containing Lyngbya confervoides. Journal of Organic Chemistry, 67: 82108215. http://dx.doi.org/10.1021/jo0261909

Madhumathi V., Deepa P., Jeyachandran S., Manoharan C. \& Vijayakumar S., 2011 - Antimicrobial activity of cyanobacteria isolated from freshwater lake. International Journal of Microbiology Research, 3: 213-216.

Matthew S., Schupp P.J. \& Luesch H., 2008 - Apratoxin $E$, a cytotoxic peptolide from a Guamanian collection of the marine cyanobacterium Lyngbya bouillonii. Journal of Natural Products, 71: 1113-1116.

http://dx.doi.org/10.1021/np700717s

Mian P., Heilmann J., Burgi H.R. \& Sticher O., 2003 Biological screening of terrestrial and freshwater cyanobacteria for antimicrobial activity, brine shrimp lethality, and cytotoxicity. Pharmaceutical Biology, 4: 243-247.

http://dx.doi.org/10.1076/phbi.41.4.243.15672

Montano E.T. \& Henderson L.O., 2013 - Studies of antibiotic production by cave bacteria. In: Cheeptham N. (Ed.), Cave Microbiomes: A novel resource for drug discovery. Springer Briefs in Microbiology, Springer New York, p. 109-130. http://dx.doi.org/10.1007/978-1-4614-5206-5 6 
Mundt S., Kreitlow S., Nowonty A. \& Effrmert U., 2001 Biological and pharmacological investigation of selected cyanobacteria. International Journal of Hygiene and Environmental Health, 203: 327-234.

http://dx.doi.org/10.1078/1438-4639-00045

Mundt S., Kreitlow S. \& Jansen R., 2003 - Fatty acids with antibacterial activity from the cyanobacterium Oscillatoria redekei HUB 051. Journal of Applied Phycology, 15: 263-267. http://dx.doi.org/10.1023/A:1023889813697

Najdenski H.M., Gigova L.G., Iliev II., Pilarski P.S., Lukavský J., Tsvetkova I.V., Ninova M.S. \& Kussovski V.K., 2013 - Antibacterial and antifungal activities of selected microalgae and cyanobacteria. International Journal of Food Science and Technology, 48: 153315440. http://dx.doi.org/10.1111/ijfs. 12122

Nicolaus B., Karambourova M. \& Oner E.T., 2010 Exopolysaccharides from extremophiles: from fundamentals to biotechnology. Environmental Technology, 31: 11451158. http://dx.doi.org/10.1080/09593330903552094

Østensvik O., Skulberg O.M., Underdal B. \& Hormazabal V., 1998 - Antibacterial properties of extracts from selected planktonic freshwater cyanobacteria: A comparative study of bacterial bioassays. Journal of Applied Microbiology, 84: 117-124. http://dx.doi.org/10.1046/j.1365-2672.1998.00449.x

Papke U., Gross E.M. \& Francke W., 1997 - Isolation, identification and determination of the absolute configuration of fischerellin B. A new algicide from the fresh water cyanobacterium Fischerella muscicola (Thuret). Tetrahedron Letters, 38: 379-382. http://dx.doi.org/10.1016/S0040-4039(96)02284-8

Plaza M., Santoyo S., Jaime L., García-Blairsy Reina G., Herrero M., Señoráns F.J. \& Ibáñez E., 2010 Screening for bioactive compounds from algae. Journal of Pharmaceutical and Biomedical Analysis, 51: 450455. http://dx.doi.org/10.1016/j.jpba.2009.03.016

Ramadan M.F., Asker M.M.S. \& Ibrahim Z.K., 2008 Functional bioactive compounds and biological activities of Spirulina platensis lipids. Czech Journal of Food Sciences, 3: 211-222.

Ramamurthy V., Raveendran S., Thirumeni S. \& Krishnaveni S., 2012 - Antimicrobial activity of heterocyte Cyanobacteria. International Journal of Advanced Life Sciences, 1: 32-39.
Sharp K., Arthur K., Gu L., Ross C., Harrison G., Gunasekera S.P., Meickle T., Matthew S., Luesch H., Thacker R.W., Sherman D.H. \& Paul V.J., 2009 Phylogenetic and chemical diversity of three chemotypes of bloom-forming Lyngbya species (Cyanobacteria: Oscillatoriales) from reefs of south-eastern Florida. Applied and Environmental Microbiology, 75: 28792888. http://dx.doi.org/10.1128/AEM.02656-08

Seufferheld M., Alvarez H.M. \& Farias M.E., 2008 Role of polyphosphates in microbial adaptation to extreme environments. Applied and Environmental Microbiology, 74: 5867-5874.

http://dx.doi.org/10.1128/AEM.00501-08

Simmons T.L., Andrianasolo E., McPhail K., Flatt P. \& Gerwick W.H., 2005 - Marine natural products as anticancer drugs. Molecular Cancer Therapeutics, 4: 333-342.

Singh O.V. \& Gabani P., 2011 - Extremophiles: radiation resistance microbial reserves and therapeutic implications. Journal of Applied Microbiology, 110: 851-861. http://dx.doi.org/10.1111/j.1365-2672.2011.04971.x

Singh R.K., Tiwari S.P., Rai A.K. \& Mohapatra T.M., 2011 - Cyanobacteria: An emerging source for drug discovery. The Journal of Antibiotics, 64: 401-412. http://dx.doi.org/10.1038/ja.2011.21

Stanier R.Y., Kunisawa R., Mandel R. \& Cohen-Bazire G., 1971 - Purification and properties of unicellular blue green algae (Order Chroococcales). Bacteriological Reviews, 35: 171-205.

Suhail S., Biswas D., Farooqui A., Arif J.M. \& Zeeshan M., 2011 - Antibacterial and free radical scavenging potential of some cyanobacterial strains and their growth characteristics. Journal of Chemical and Pharmaceutical Research, 3: 472-478.

Uzair B., Tabassum S., Rashed M. \& Rehman S.F., 2012 - Exploring marine Cyanobacteria for lead compounds of pharmaceutical importance. The Scientific World Journal, 2012: 1-10.

http://dx.doi.org/10.1100/2012/179782

Vijaya Baskara Sethubathi G. \& Ashok Prabu V., 2012 - Antibacterial activity of cyanobacterial species from Adirampattinam Coast, Southeast Coast of Palk Bay. Current Research Journal of Biological Sciences, 2: 24-26.

Zainuddin E.N., Mundt S., Wegner U. \& Mentel R., 2002 Cyanobacteria a potential source of antiviral substances against influenza virus. Medical Microbiology and Immunology, 191: 181-182. http://dx.doi.org/10.1007/s00430-002-0142-1 